\title{
ВИКОРИСТАННЯ ВІДХОДІВ ПОЛІСТИРОЛУ ДЛЯ ЗАХИСНОГО ПОКРИТТЯ БЕТОННИХ ПІДЛОГ
}

\section{USE OF WASTE POLYSTYRENE FOR PROTECTIVE COATING OF CONCRETE FLOORS.}

Піддубний С.В., ст. викл., Соколенко В.М., к.т.н., доцент, Білошицький М.В., к.т.н., доцент, Шпарбер М.С., ст. викл. (Східноукраїнський національний університет імені Володимира Даля. м. Сєвєродонецьк)

Piddubnyi S. V., senior lecturer, Sokolenko V. M., PhD., associate professor, Biloshytskiy M. V., PhD., associate professor, Shparber M. E, senior lecturer (Volodymyr Dahl East Ukrainian National University. Severodonetsk)

Розглянуто можливість використання відходів полістиролу в якості засобу для поверхневого просочення бетонної підлоги. Пропоновано використовувати розчинений в толуолі полістирол для покриття підлог виробничих приміщень як речовину, щзо зміцнює верхній шар, захищає від вологи та пригнічує пил. Описана технологія приготування розчину і нанесення на поверхню бетонної підлоги.

Increased demands are placed on the floors of industrial buildings in terms of resistance to mechanical stress.

Concrete, which is most often used for the manufacture of highly loaded floors of industrial buildings and structures, has many positive qualities: high wear resistance, low cost, simplicity and speed of installation. But concrete also has some negative qualities associated with its low tensile strength and porosity.

To strengthen the concrete floor and eliminate the possibility of dust formation, such technologies as impregnation with reinforcing compounds are used.

The authors of the article propose to use waste polystyrene dissolved in toluene as a protective, hydrophobic and reinforcing coating for floors of industrial premises.

Polystyrene dissolves easily in toluene. A solution is formed in the form of a clear liquid with a certain viscosity. With the help of special devices, the resulting solution can be applied to the surface of concrete floors. Mechanical application of the finished solution is carried out using airless spraying devices. 
The coating provides bonding of the existing dust particles on the floor surface with a strong polymer film. The polymer penetrates into the pores of concrete to a depth of 1 to $3 \mathrm{~mm}$, depending on the porosity of the concrete. The concrete structure becomes denser and stronger, and the surface becomes waterproof.

After impregnation with a composition based on polystyrene, the performance properties of concrete floors increase, and the top layer of the concrete floor is strengthened and hardened. Floors emit less dust, become chemically resistant, and abrasion resistance increases. Such floors have an aesthetic appearance, are easy to maintain and can be easily repaired. The use of polystyrene waste significantly reduces the cost of work in comparison with prefabricated impregnations. The floors can be used 2 hours after impregnation, which makes it possible to use this composition in existing enterprises.

Ключові слова: бетонна підлога; полістирол; гідрофобне покриття; просочення бетонних підлог.

Key words: concrete floor; polystyrene; hydrophobic coating; impregnation of concrete floors.

Підлога - один з найважливіших елементів конструкції та інтер'єру будівлі, який сприймає експлуатаційні впливи.

До підлоги пред'являється комплекс різноманітних вимог конструктивних, експлуатаційних, санітарно-гігієнічних, декоративних та ін., що залежать від призначення приміщення. До підлог промислових будівель пред'являють підвищені вимоги по опірності механічним впливам (стирання, удару тощо), а для деяких виробництв - по хімічній стійкості, теплостійкості та ін [1].

Для виготовлення високонавантажених підлог промислових будівель i споруд найчастіше застосовується бетон. Бетон володіє багатьма позитивними якостями: високою зносостійкістю, дешевизною, простотою і швидкістю укладання. Але у бетону є і деякі негативні якості, пов'язані 3 його низькою міцністю на розтяг і пористістю.

Сама по собі бетонна плита може витримати дуже високе навантаження, але верхній шар виявляється найслабшою ланкою і дуже часто буває причиною руйнування самої плити. Так як саме верхній шар сприймає всі несприятливі навантаження від зовнішніх умов i умов експлуатації. Якщо верхній шар недостатньо щільний i міцний, то несприятливі фактори та речовини проникають в товщу бетону i викликають його руйнування. 
При експлуатації бетонної підлоги ії верхній шар під навантаженням постійно стирається і зношується - i бетон пилить. Утворення пилу на поверхні бетону підлоги - явище поширене i, як правило, очевидне тільки після початку його експлуатації. Характерний бетонний пил утворюється через вихід на поверхню солей і руйнування слабкого поверхневого шару, що складається з цементу, пилу, наповнювачів і різних забруднень.

Цей пил несе реальну загрозу здоров'ю людей, оскільки він піднімається в повітря і проникає в легені людини. Також пил від бетонних підлог небезпечний i для виробництва і може унеможливити роботу цеху. Збільшення запиленості приміщень на деяких виробництвах і накопичення пилу на елементах будівельних конструкцій і технологічному обладнанні можуть призвести до вибуху при появі джерела займання.

Для знепилювання і зміцнення бетонної підлоги застосовують такі технології, як топпінг (нанесення на свіжий бетон сухих зміцнюючих сумішей) і просочення зміцнюючими складами.

Топпінг можна застосовувати тільки на поверхні плити, яка якісно армована і залита бетоном класу не нижче C16/20. Зміцнюючу суміш наносять на свіжий бетон, який ще не встиг затвердіти, але вже схопився. Зазвичай роботи починають через 5-8 годин після укладання бетонної суміші.

Речовину для поверхневого просочення можна наносити на вже експлуатовану бетонну підлогу, попередньо підготувавши іiі поверхню. На сьогоднішній день для просочення бетонних підлог використовують велику кількість різних складів - як неорганічних, на основі фторсилікатів (флюати), так і органічних, склад яких більш різноманітний. У групу органічних входять акрилові, поліуретанові та епоксидні розчини та суміші. Акрилові просочення вважаються найслабшими. Їх можна використовувати тільки в тому випадку, якщо бетонні підлоги будуть піддаватися невеликим навантаженням.

У випадку заповнення пор та мікрокапілярів в бетоні, ці просочення блокують шляхи руху води, істотно збільшують щільність, зносостійкість і знижують пиловиділення бетонної поверхні, спрощують догляд за поверхнею.

3 точки зору проникності пари води матеріали поділяються на проникні, в основному до них відносяться мінеральні покриття, i непроникні. До останніх відносяться полімерні покриття (епоксидні, 
поліуретанові, метилметакрилатні тощо). Однак в даний час випускаються полімерні матеріали, які володіють проникністю до пари води.

Характеристики по проникності до водяної пари для покриттів повинні наводитися за інструкцією заводу виробника. Їх можна визначити також в лабораторних умовах. Порівняльні характеристики по проникності в конструкціях можуть бути визначені за ДСТУ Б в.2. 7-170: 2008 [2].

Авторами статті пропонується в якості захисного, пило-, гідрофобного і зміцнюючого покриття для підлог виробничих приміщень використовувати відходи полістиролу, розчиненого в толуолі.

Полістирол - це термопластичний полімер з лінійною структурою, що $€$ продуктом полімеризації стиролу [3]. Його фізичні та хімічні характеристики, а також експлуатаційні властивості залежать від способу отримання, молекулярної маси, полідисперсності та інших факторів. Полістирол виробляють литтям під тиском і екструзією при високих температурах.

Сфера застосування полістиролу досить широка. Його використовують у цивільній і військовій промисловості, машинобудуванні, електротехніці, будівництві, приладобудуванні, медицині, харчовій промисловості, для зовнішнього та внутрішнього декоративного оздоблення приміщень, а також для виготовлення різних побутових предметів $[3,4,5]$.

Полістирол загального призначення [3] це прозорий матеріал, який добре фарбується, легко переробляється, призначений для виготовлення виробів різними методами термоформування.

Різні види полістиролу відрізняються за механічними i температурними властивостями в певних вузьких межах. Різновиди полістиролу зручно порівнювати за показниками температури плавлення, яка змінюється в межах від $513 \mathrm{~K}^{0}$ для ізотактичного полістиролу до $583 \mathrm{~K}^{0}$ для полідиметилстиролу.

Толуол - продукт каталітичного риформінгу бензинових фракцій нафти [6]. Також толуол отримують при піролізі вугілля. Він виготовляється в значних кількостях на коксохімічних заводах України. Толуол є розчинником для багатьох полімерів, входить до складу різних товарних розчинників для лаків і фарб та застосовується як розчинник в хімічному синтезі.

Полістирол легко розчиняється в толуолі, утворюється розчин у вигляді прозорої рідини з деякою в'язкістю (приблизно по консистенції 
рівній гліцерину). За допомогою спеціальних пристроїв отриманий розчин можна наносити на поверхню бетонних підлог.

Покриття забезпечує зв'язування наявних пилоподібних частинок на поверхні підлог міцною полімерною плівкою. Полімер проникає в пори бетону на глибину від 1 до 3 мм, залежно від пористості. Структура бетону стає більш щільною і міцною, поверхня стає водонепроникною.

Механічне нанесення готового розчину рекомендується проводити за допомогою апаратів безповітряного напилення. Принцип дії таких апаратів заснований на розпиленні рідких матеріалів під високим тиском через спеціальні форсунки (сопла) з маленьким розміром отвору. При цьому на виході отвору створюється факел 3 розпорошуваного матеріалу 3 рівномірним розподілом. Форма факела може бути конусоподібною (при круглому отворі), або плоскою у вигляді трикутника (при щілиноподібному отворі).

Для покриття $1000 \mathrm{~m}^{2}$ підлог виготовляють приблизно $1 \mathrm{~m}^{3}$ робочого розчину. Для цього в металеву ємність-змішувач об'ємом $1,5 \mathrm{~m}^{3} 3$ відміткою на $1 \mathrm{~m}^{3}$ обсягу заливають $\sim 0,8 \mathrm{~m}^{3}$ толуолу, додають дробовими порціями полістирол і перемішують до повного розчинення кожної 3 доданих порцій. Обсяг або маса кожної доданої порції полістиролу вибирається відповідно до незаповненої частини обсягу змішувача, який розрахований відповідно до відношення: 1 обсяг виготовленого розчину до 1,5 обсягу ємності-змішувача, тобто дозволяє завантаження кожної дробової порції не більше 0,5 обсягу виготовленого розчину. Об'ємна вага полістиролу в разі використання відходів (пінопласту) може перевершувати обсяг виготовленого розчину в десятки разів, що не дозволяє завантажити в один прийом всю необхідну масу (15\% або на $1 \mathrm{~m}^{3}$ - 15 кг).

Після повного розчинення полістиролу доводять об'єм до $1 \mathrm{~m}^{3}$ чистим толуолом. Необхідно переконатися в чистоті отриманого розчину щодо механічних домішок. Якщо домішки виявлені (взяття проби на просвіт в скляній ємності 0,5 л), то розчин необхідно відфільтрувати через 2 шари бавовняної тканини (парусина або мішковина тощо).

Розчин для покриття готують однією порцією на всю площу підлог 3 розрахунку $1 \mathrm{~m}^{3}$ на $1000 \mathrm{~m}^{2}$ або дробовими порціями, наносячи по частинах кожну чергову виготовлену дозу. Смність вибирають залежно від площ i обраного режиму робіт. Виготовлення великих партій більш економічно, проте вимагає використання механізації: насос для заповнення, механічна 
мішалка для перемішування, ємність, починаючи 3 обсягу більше $1 \mathrm{~m}^{3}$. Ручне перемішування не $є$ доцільним.

Перед початком робіт з підлог видаляється сміття і пил механічним сухим або мокрим способом. Підлоги просушують. Покриття наносять на суху поверхню.

Відповідно до ДСТУ ГОСТ 31906:2019 [6] толуол відноситься до паливно-летючих рідин III класу токсичності. ГДК в робочій зоні складає 0,05 г / $\mathrm{m}^{3}$ повітря.

Згідно з вимогами правил охорони праці та пожежної безпеки на період робіт приміщення необхідно забезпечити припливно-витяжною вентиляцією.

Час висихання підлог після нанесення покриття - від 20 хв. до 1 години. Якщо ГДК по толуолу в повітрі перевищує рівень 0,05 г/м ${ }^{3}$ повітря, то роботи 3 покриття ведуть із перервами на висихання i провітрювання приміщень після кожної смуги нанесення робочої суміші.

Висновок. Після просочення складом на основі полістиролу поліпшуються експлуатаційні властивості бетонних підлог, зміцнюється верхній шар бетонної підлоги. Підлоги не продукують пил, стають хімічно стійкими, підвищується спротив на стирання. Такі підлоги мають естетичний зовнішній вигляд, прості в догляді і легко ремонтуються. Застосування відходів полістиролу значно знижує вартість робіт у порівнянні з просоченнями заводського виготовлення (на сьогоднішній день відходи полістиролу коштують від 8 грн/кг). Експлуатувати підлоги можна через 2 години після просочення, що дає можливість використовувати цей склад на діючих підприємствах.

\section{References}

1. Zarubyna L. P. Z-34 Ustroistvo polov. Materyaly y tekhnolohyy. - SPb.: BKhV-Peterburh, 2011. — 320 s.: yl. — (Stroytelstvo y arkhytektura)ISBN 978-5-97750699-1

2. DSTU B V.2.7-170:2008. Budivelni materialy. Betony. Metody vyznachennia serednoi hustyny, volohosti, vodopohlynannia, porystosti i vodonepronyknosti. [Chynnyi vid 2009-07-01]. Vyd. ofits. Kyiv : DP "Derzhavnyi naukovo-doslidnyi instytut budivelnykh konstruktsii (NDIBK)", 2008. 
3. Novyi spravochnyk khymyka y tekhnoloha. Syre y produkty promyshlennosty orhanycheskykh y neorhanycheskykh veshchestv. Ch. II. - S. Pb.: ANO NPO «Professyonal», 2005, 2007. - 1142 s.

4. DSTU B EN 13163:2012 Materialy budivelni teploizoliatsiini Vyroby zi spinenoho polistyrolu (EPS) Tekhnichni umovy (EN 13163:2008, IDT). [Chynnyi vid 2013-04-01]. Vyd. ofits. Kyiv : «NTP-STANDART», 2014.

5. DSTU B EN 13164:2013 Materialy budivelni teploizoliatsiini. Vyroby iz ekstrudovanoho pinopolistyrolu (XPS). Tekhnichni umovy (EN 13164:2008, IDT). [Chynnyi vid 2014-04-01]. Vyd. ofits. Kyiv : «NTP-STANDART», 2014.

6. DSTU HOST 31906:2019 Toluol naftovyi. Tekhnichni umovy (HOST 319062013, IDT) [Chynnyi vid 2019-06-10]. Vyd. ofits. Kyiv : DP «UkrNDNTs», 2019. 10 s.

\section{Список використаних джерел}

1. Зарубина Л. П. 3-34 Устройство полов. Материалы и технологии. - СПб.: БХВ-Петербург, 2011. — 320 с.: ил. — (Строительство и архитектура) ISBN 978-59775-0699-1

2. ДСТУ Б В.2.7-170:2008. Будівельні матеріали. Бетони. Методи визначення середньої густини, вологості, водопоглинання, пористості і водонепроникності. [Чинний від 2009-07-01]. Вид. офіц. Київ : ДП "Державний науково-дослідний інститут будівельних конструкцій (НДІБК)", 2008.

3. Новый справочник химика и технолога. Сырьё и продукты промышленности органических и неорганических веществ. Ч. ІІ. - С. Пб.: АНО НПО «Профессионал», 2005, 2007. - 1142 с.

4. ДСТУ Б ЕN 13163:2012 Матеріали будівельні теплоізоляційні Вироби зі спіненого полістиролу (EPS) Технічні умови (EN 13163:2008, IDT). [Чинний від 2013-04-01]. Вид. офіц. Київ : «НТП-СТАНДАРТ», 2014.

5. ДСТУ Б ЕN 13164:2013 Матеріали будівельні теплоізоляційні. Вироби із екструдованого пінополістиролу (XPS). Технічні умови (EN 13164:2008, IDT). [Чинний від 2014-04-01]. Вид. офіц. Київ : «НТП-СТАНДАРТ», 2014.

6. ДСТУ ГОСТ 31906:2019 Толуол нафтовий. Технічні умови (ГОСТ 319062013, IDT) [Чинний від 2019-06-10]. Вид. офіц. Київ : ДП «УкрНДНЦ», 2019. 10 с. 